\title{
DEVELOPMENT OF Tetranychus urticae KOCH (ACARI: TETRANYCHIDAE) IN DIFFERENT STRAWBERRY CULTIVARS ${ }^{1}$
}

\author{
FÁBIO KARLEC ${ }^{2}$, ADRIANE DA FONSECA DUARTE ${ }^{3}$, \\ ANA CLÁUDIA BARNECHE DE OLIVEIRA ${ }^{4}$, UEMERSON SILVA DA CUNHA ${ }^{5}$
}

\begin{abstract}
Two-spotted spider mite, Tetranychus urticae Koch, is considered the main pest in strawberry crop. The control of this species is hampered by the low efficiency of products currently used, occurrence of populations resistant to acaricides and high reproductive potential of this pest. This leads to the use of pesticides and increased agrochemical residues in fruits. The use of resistant cultivars is considered the ideal control method because they maintain mite populations below levels of economic damage, minimize the environmental impact of pesticides at no extra cost to the farmer, and serve as an auxiliary tool in integrated pest management. In this sense, this study evaluated the resistance of strawberry cultivars to T. urticae by studying the development of its biological aspects. Comparative biology experiments and non-preference tests for feeding and oviposition for spider mite were carried out in 16 strawberry cultivars under laboratory conditions. Based on results, it was found that Camarosa, Florida Festival, IAC Campinas and Sabrosa strawberry cultivars indicated the possibility of antibiosis type resistance to spider mite, influencing the preference to food, development and oviposition, indicating the existence of differentiated reaction in population development among cultivars.
\end{abstract}

Index terms: two-spotted spider mite, comparative biology, antixenosis.

\section{DESENVOLVIMENTO DE Tetranychus urticae KOCH (ACARI: TETRANYCHIDAE) EM DIFRENTES CULTIVARES DE MORANGUEIRO}

\begin{abstract}
RESUMO - O ácaro-rajado, Tetranychus urticae Koch, é considerado a principal praga da cultura do morangueiro. O controle desta espécie é dificultado pela baixa eficiência dos produtos atualmente empregados, pela ocorrência de populações resistentes a acaricidas e ao alto potencial reprodutivo dessa praga. Isso induz ao uso de agrotóxicos e ao aumento de resíduos de agroquímicos na fruta. $\mathrm{O}$ emprego de cultivares resistentes é um método de controle considerado ideal, pois permite a manutenção do ácaro em níveis inferiores aos de dano econômico, minimiza o impacto ambiental dos agrotóxicos, sem ônus adicional ao agricultor, e serve como ferramenta auxiliar no manejo integrado da praga. Nesse sentido, o trabalho avaliou a resistência de cultivares de morangueiro a T. urticae através do estudo do desenvolvimento de seus aspectos biológicos. Experimentos de biologia comparada, testes de não preferência à alimentação e a oviposição para o ácarorajado foram conduzidos em 16 cultivares de morangueiro em condições de laboratório. A partir dos estudos, constatou-se que as cultivares Camarosa, Florida Festival, IAC Campinas e Sabrosa indicaram a possibilidade da existência de resistência do tipo antibiose para o ácaro-rajado, influenciando na preferência à alimentação, desenvolvimento e oviposição, indicando a existência de reação diferenciada entre as cultivares estudadas. Termos para indexação: ácaro-rajado, biologia comparada, antixenose.
\end{abstract}

\footnotetext{
1(189-15). Received July 31, 2015. Accepted August, 2016.

${ }^{2}$ Agronomist, MSc, Dept. of Plant Crop Protection / FAEM / UFPel, Maiolbox 354, Zip Code 96010-900, Pelotas-RS. Email: fabiokarlec@yahoo.com.br

${ }^{3}$ Agronomist, MSc, Dept. of Plant Crop Protection / FAEM / UFPel, P.Box 354, Zip Code 96010-900, Pelotas-RS. Email: adriane faem@hotmail.com

${ }^{4}$ Agronomist, Dr. Researcher at Embrapa Clima Temperado, P.Box 403, Zip Code: 96001970, Pelotas-RS. Email: ana.barneche@ embrapa.br

${ }^{5}$ Agronomist, Dr. Professor at the Dept. of Plant Crop Protection / FAEM / UFPel, P.Box 354, Zip Code: 96010-900, Pelotas-RS. Email: uscunha@yahoo.com.br
} 


\section{INTRODUCTION}

Strawberry (Fragaria $x$ ananassa Duch) is cultivated worldwide, including in several states of Brazil such as Minas Gerais, Rio Grande do Sul and São Paulo (ANTUNES; DUARTE FILHO, 2005). Strawberry cultivation is highly developed especially in temperate regions, requiring large amounts of labor, usually family labor, being of great economic and social importance (FERLA; MARCHETTI; GONÇALVES, 2007).

Several diseases and pests can significantly compromise strawberry production, among them Tetranychus urticae Koch (Tetranychidae), a polyphagous pest that can cause losses of up to $80 \%$ in strawberry crop (FADINI et al., 2004; MORAES; FLECHTMANN, 2008; SATO et al., 2009). When feeding, spider mite causes damage to the foliar mesophyll cells and closure of stomata, reducing the photosynthetic rate of plants, causing discoloration and tanning of leaves, which leads to a reduction in number and weight of fruits and consequently of productivity (MORAES, FLECHTMANN, 2008).

In most strawberry crops, control of the spider mite is almost exclusively performed with the use of agrochemicals, whose environmental impact under certain circumstances can be quite significant (WATANABE et al., 1994; BERNARDI et al., 2013). In addition, the control of $T$. urticae is hampered by its high reproductive potential and low efficiency of products used, mainly due to the existence of several populations of this species resistant to acaricides such as abamectin and fenpyroximate (SATO et al., 2009).

Within the correct practices of strawberry crop management, the control of the spider mite has received more attention, mainly for the search of alternatives to conventional chemical control. One of the alternatives is the reduction in the use of agrochemicals, aiming at the production of fruit free of toxic residues and healthy to consumers through the use of biological control with predatory mites associated to the use of natural products. (BERNARDI et al., 2013).

Another alternative is the use of plants resistant to the pest, as it allows the maintenance of a certain population at levels below those of economic damage. This practice minimizes the use of agrochemicals and has no additional cost to the farmer, and serves as an auxiliary tool in integrated management, which can be associated with other pest management practices (LARA, 1991). Some studies have demonstrated the existence of different levels of susceptibility and resistance to spider mite in strawberry crops (LOURENÇÃO et al., 2000;
LABANOWSKA, 2007; MONTEIRO et al., 2014; REZAIE et al., 2013). However, researches with cultivars of great commercial expression adapted to Brazilian producing regions are still underdeveloped.

Considering the above and based on the premise that strawberry cultivars available in the market present a differentiated response regarding resistance to the mite, the development of the spider mite in strawberry crop was evaluated in laboratory through the study of the biological aspects in different cultivars.

\section{MATERIAL AND METHODS}

Comparative biology experiments and non-preference tests for feeding and oviposition were carried out at the Laboratory of Acarology, Department of Plant Crop Protection -Sciences of the "Eliseu Maciel" Agronomy School, Federal University of Pelotas, RS. The mites used in the research were collected in the municipality of Arroio do Padre, RS ( $31^{\circ} 26^{\prime} 30.55^{\prime \prime} \mathrm{S}$ and $52^{\circ} 25^{\prime} 07.25^{\prime \prime} \mathrm{W}$ and $252 \mathrm{~m}$ asl), four months before the beginning of tests. The stock-colony of these mites was maintained in bean plants (Phaseolus vulgaris L.) at vegetative stage grown in $4.5 \mathrm{~L}$ pots in greenhouse.

In this study, 16 strawberry cultivars were used: Albion, Aromas, Camarosa, Campidover, Camino Real, Diamante, Dover, Florida Festival, IAC Campinas, IAC Guarani, Monterrey, Oso Grande, Serrana, Sabrosa, Toyonoka and Ventana. Plants were grown in pots with culture-specific substrate. The management practices were the same for all cultivars, being kept in greenhouse, spraying neem oil at dosage of $3 \mathrm{ml}$. L-1 of water every 20 days to prevent infestation of insects and mites. A 20-day shortage interval of the product for the use of plants for tests was respected.

The study design was completely randomized, with 16 strawberry cultivars and 20 replicates. Each replicate consisted of a Petri dish of $10 \mathrm{~cm}$ in diameter, lined with cotton moistened with distilled water. On the cotton and with the abaxial side facing up, a leaf disc with $22 \mathrm{~mm}$ of diameter was arranged, collected from a leaflet of each cultivar collected from the middle part of plants with age of eight months.

An adult T. urticae female in the oviposition period from the stock colony was transferred with the aid of a fine brush to each leaf disc so that oviposition occurred. After 12 hours, an egg was kept in each leaf disc, from which the development was followed, with female and the rest of the eggs being discarded. Dishes containing the leaf discs were kept in an air- 
conditioned room at temperature of $25 \pm 2{ }^{\circ} \mathrm{C}, \mathrm{RH}$ of $70 \pm 10 \%$ and photoperiod of $12 \mathrm{~h}$.

Evaluations were performed every 24 hours, and the duration and survival of egg stages, immature (larva, protonymph and deutonymph), adult, duration of oviposition periods, longevity and daily oviposition were also evaluated. During the adult phase, individuals were separated by sex. The viability of eggs was evaluated using eggs from the three initial evaluations of the oviposition period by females in each cultivar.

Based on age (x), specific fertility $(\mathrm{mx})$ and survival probability (lx) data, fertility life table 3 was elaborated according to Silveira Neto et al. (1976), calculating the net reproduction rate (Ro), time interval between each generation $(\mathrm{T})$, innate ability to increase in number ( $\mathrm{rm}$ ), finite increase rate $(\lambda)$, defined as the number of times the population multiplies in a time unit and the time needed for the population to double in number of individuals (TD), where: Ro $=\Sigma(\mathrm{mx} .1 \mathrm{x}), \mathrm{T}=(\Sigma \mathrm{mx} .1 \mathrm{~lx} . \mathrm{x}) /(\Sigma \mathrm{mx} . \mathrm{lx})$,

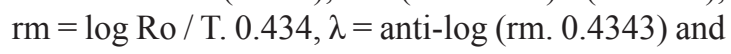
$\mathrm{TD}=\operatorname{Ln}(2) / \mathrm{rm}$.

Data were submitted to analysis of variance using the F test and means were compared by the Duncan test, with $5 \%$ probability.

\section{RESULTS AND DISCUSSION}

\section{Development of Tetranychus urticae in different strawberry cultivars}

The development of the spider mite was influenced by the different cultivars studied, whose effects were observed in the biological parameters of larva, protonymph and adult (Table 1). For the egg and deutonymph phases, no significant differences were observed among cultivars studied.

The duration of the T. urticae larva stage ranged from 3.0 to 6.4 days, with Camarosa and Sabrosa cultivars providing the highest durations of the larval stages, with an average of 6.3 days, differing from the Albion, Camino Real, Dover, Monterey and Oso Grande cultivars, which presented the shortest durations of this stage, with average of 3.3 days. The protonymph duration was higher in IAC Guarani cultivar, with average of 5.1 days, differing from Albion, Camarosa, Campidover and Oso Grande cultivars, which presented average of 2.4 days.

As for the adult stage of mites, Albion cultivar provided the longest duration with 14.1 days, differing from Campinas cultivar, which showed the shortest duration, 7.0 days. Regarding the oviposition period, mites that fed on Camarosa and Sabrosa cultivars presented the shortest durations, with 6.1 and 7.4 days respectively, significantly differing from Dover cultivar, in which the mites had oviposition period of 13.9 days (Table 1).

According to Awmack and Leather (2002), the nutritional characteristics, as well as the physiological and biochemical changes of the host plant, influence the development of an herbivore. Krips et al. (1998) reported that the development of T. urticae can be influenced both by host species and by intraspecific variations, that is, among different cultivars or materials of the same species.

Monteiro et al. (2014) showed differences in T. urticae development time in different strawberry genotypes, with Camarosa, Diamante and Seascape cultivars having the most negative effects on the mite. On average, the duration of the development period of the spider mite for strawberry cultivars were higher than those presented by other authors in other hosts, also showing variation among cultivars, being or not able to favor the development of the pest species, either by chemical or morphological factors.

Moro et al. (2012) analyzed the duration of the developmental period of T. urticae in papaya cultivars and observed variation in the duration of the egg-adult period between 9.4 and 10.2 days. Silva et al. (1985) and Esteves Filho et al. (2010), in similar works in cotton cultivars, observed duration in the egg-adult period between 10.6 and 10.7 days, and 8.9 and 9.3 days, respectively.

The greater prolongation of immature stages and the lower survival at this stage are generally related to the chemical or nutritional characteristics of the host, in which prolongation is caused by a condition unfavorable to the individual development, and acceleration, on the contrary, shows that the host meets nutritional needs to quickly reach the adult stage. However, after reaching the adult stage, the interest regarding the resistance of plants to arthropods is in the shortest duration of this phase, which would lead to lower feeding rate and injuries and damage to the plant, as well as lower reproductive capacity.

The results of this experiment showed a prolongation of the immature period in mites most prominently in Camarosa, Sabrosa and IAC Campinas cultivars when compared to Albion and Oso Grande cultivars, in which the development was more accelerated, which can be interpreted as indicative of antibiosis-type resistance for IAC Campinas cultivar and to a lesser degree for Sabrosa and Camarosa cultivars, which corroborates the work of Monteiro et al. (2014), who observed a delay in the development of $T$. urticae larva and protonymph 
stages in Camarosa cultivar, indicating that these cultivars require a higher cost of adaptation to the mite than the other cultivars.

\section{Survival of Tetranychus urticae in different strawberry cultivars}

Survival in the different development stages

of $T$. urticae (Table 2) showed a significant difference among cultivars for egg, larva and egg-adult stages. The highest mortality occurred in the larval stage, with survival percentage ranging from 38.9 (Florida Festival) to $80.0 \%$ (Serrana), demonstrating that this stage is the most sensitive to the resistance effects of plants under study. In the egg, protonymph and deutonymph stages, survival was at least 80.2, 77.8 and $61.4 \%$, respectively. According to Monteiro et al. (2014), T. urticae presented greater establishment difficulty in strawberry leaf discs in the larval stage, possibly due to the presence of components that may have toxic or anti-digestive effects in the initial stages of herbivores.

The accumulated survival in the egg-adult period evidences the influence of cultivars on development, since it represents the percentage of individuals that reach the adult stage from the egg stage. Diamante, Aromas, Florida Festival and Sabrosa cultivars presented the smallest survival percentage of mites in the egg-adult period, with $26.7,27.4,27.8$ and $27.8 \%$, respectively. On the other hand, Oso Grande cultivar, followed by Toynoka, Serrana and Monterrey cultivars were the most favorable to the development of T. urticae, presenting the highest percentage of individuals that reached adulthood, with 61.1, 55.6, 53.8 and 53.3\%, respectively. In the other cultivars tested, survival varied from 52.8 to $30.5 \%$.

The presence of glandular and non-glandular trichomes may have influenced the survival of the spider mite, either by exudation of adhesive substances that limit displacement or by the toxic effect on mites, as observed by other studies (LUCZYNSKI et al., 1990; STEINITE; EVINSH, 2003; GONÇALVES et al., 2006; FIGUEIREDO et al., 2010). However, Kishaba et al. (1972) observed that non-glandular trichomes were favorable to $T$. urticae infestations on strawberry leaves. In this context, the possibility of influence of the host plant chemical characteristics cannot be ruled out, which, in addition to interfering with development, may lead to premature death of the mite.

It was also observed that not all cultivars that had positive or negative influence on T. urticae development had an equal degree of interference on survival, thus showing the possible action of more than one resistance factor, either biochemical or morphological, with independent relation and differentiated expression in hosts.

\section{Tetranychus urticae fertility life table}

Based on net reproductive rate (Ro), intrinsic growth rate $(\mathrm{rm})$, population doubling time $(\mathrm{Td})$ and finite increase rate $(\lambda)$ data, a condition more favorable to the population growth of mites fed on Monterrey, Serrana and Oso Grande cultivars, and a less favorable condition on Florida Festival, IAC Campinas and Dover cultivars was evidenced.

The net reproductive rate (Ro), which corresponds to the average contribution of each female to the next generation, expressed in number of female offspring per female, varying from 14.84 to 1.96 females / female, the lowest rate was obtained in mites fed on Florida Festival, IAC Campinas and Dover cultivars, with 1.96, 2.96 and 2.97 females / female, respectively. However, Monterrey, Serrana and Oso Grande cultivars presented the highest net reproduction rates, with values of 14.84, 13.42 and 11.28 , respectively. The lower net reproduction rate observed when Florida Festival cultivar was used to feed T. urticae females is strongly related to the negative influence of this material on oviposition and survival, since no differences were observed for sex ratio.

The intrinsic growth rate (rm), that is, the innate ability to increase in number, ranged from 0.030 (Florida Festival) to 0.120 (Monterrey). Population doubling time (Td) ranged from 23.12 (Florida Festival) to 5.77 days (Monterrey). This means that when compared to Florida Festival cultivar, Monterrey cultivar has population increase capacity four times greater.

The finite increase rate $(\lambda)$ represents a population multiplication factor within a time interval, and can be expressed as daily growth rate in percentage. This rate was higher in Monterrey cultivar, with $12.8 \%$ and lower in Florida Festival cultivar, with $3.0 \%$. The mean interval between generations (IMG) ranged from 21.56 (Oso Grande) to 25.34 days (Camarosa), not showing the same trend as the other life Table 3 parameters.

According to Moro et al. (2012), as estimated from breeding and mortality values, Ro values have important influence on the population growth of the mite. In works comparing $\mathrm{Ro}, \mathrm{rm}, \mathrm{Td}$ and $\lambda$ parameters in different Carica papaya L. cultivars, these authors observed differences in T. urticae development, ranging from 106.7 to 76.5 females / female. Analyzing the influence of different cotton cultivars, Silva et al. (1985) observed Ro values 
varying from 40 to 48 females / female. Kasap (2004) also observed difference in Ro values of T. urticae among Malus domestica (Borkh) cultivars, observing oscillation between 64 and 92 females / female.

The Ro parameter has a direct influence on the intrinsic increase rate $(\mathrm{rm})$, which probably led $\mathrm{rm}$ to present the same variation trends among cultivars as for Ro. The rm, Td and $\lambda$ values observed in this work also presented variations, as evidenced by other authors (SILVA et al., 1985, KASAP, 2004; MORO et al., 2012), thus showing intra-specific and interspecific variations in the mite development relative to its host (species or cultivar).

The differences observed in population growth rates are information that can serve as a basis for control decision-making, since according to Lourenção et al. (2000), strawberry cultivars that had the lowest symptoms of T. urticae attack were those that showed the smallest infestations.
The results presented in this work can help in the development of strategies in the mite integrated management and will serve as a base for the improvement of strawberry cultivars aiming at the development of more resistant cultivars. The information presented here is also useful at field level for fruit growing, and can be added to other control methods such as the biological one, being an alternative for the reduction of use of pesticides in the control of this pest in strawberry crops.

However, further studies on plant tolerance and deepening the resistance factors involved in the process of plant defense against the development of the spider mite are necessary to characterize the events involved in the process that provide resistance.

TABLE 1 - Average length in days of egg, larva, protonymph, deutonymph, adult and oviposition of Tetranychus urticae females grown on leaves of different strawberry cultivars in the laboratory, with no choice test. Pelotas-RS, 2015.

\begin{tabular}{lccccccc}
\hline \multirow{2}{*}{ Cultivars } & \multicolumn{7}{c}{ Stages } \\
\cline { 2 - 6 } & Egg & Larva & Protonymph & Deutonymph & Adult & Oviposition \\
\hline Camarosa & $4,1(0,21) \mathrm{a}$ & $6,4(0,83) \mathrm{a}$ & $2,3(0,80) \mathrm{b}$ & $2,4(0,42) \mathrm{a}$ & $11,3(1,80) \mathrm{ab}$ & $6,1(1,97) \mathrm{b}$ \\
Sabrosa & $3,9(0,21) \mathrm{a}$ & $6,1(0,83) \mathrm{ab}$ & $3,3(0,80) \mathrm{ab}$ & $3,4(0,42) \mathrm{a}$ & $8,3(1,80) \mathrm{ab}$ & $7,4(1,97) \mathrm{b}$ \\
IAC Campinas & $4,3(0,21) \mathrm{a}$ & $5,9(0,83) \mathrm{abc}$ & $4,0(0,80) \mathrm{ab}$ & $3,1(0,42) \mathrm{a}$ & $7,0(1,80) \mathrm{a}$ & $7,9(1,73) \mathrm{ab}$ \\
Aromas & $4,0(0,23) \mathrm{a}$ & $5,8(0,89) \mathrm{abc}$ & $3,7(0,87) \mathrm{ab}$ & $2,7(0,46) \mathrm{a}$ & $9,8(1,95) \mathrm{ab}$ & $8,8(2,12) \mathrm{ab}$ \\
Campidover & $3,9(0,21) \mathrm{a}$ & $5,0(0,83) \mathrm{abcd}$ & $2,3(0,80) \mathrm{b}$ & $2,6(0,42) \mathrm{a}$ & $10,1(1,80) \mathrm{ab}$ & $8,4(1,57) \mathrm{ab}$ \\
Diamante & $4,2(0,23) \mathrm{a}$ & $4,5(0,89) \mathrm{abcd}$ & $3,0(0,87) \mathrm{ab}$ & $2,8(0,46) \mathrm{a}$ & $10,5(1,95) \mathrm{ab}$ & $10,7(1,97) \mathrm{ab}$ \\
Ventana & $3,9(0,17) \mathrm{a}$ & $4,5(0,83) \mathrm{abcd}$ & $3,8(0,64) \mathrm{ab}$ & $3,5(0,34) \mathrm{a}$ & $9,8(1,44) \mathrm{ab}$ & $7,7(1,97) \mathrm{ab}$ \\
Serrana & $4,0(0,17) \mathrm{a}$ & $4,4(0,66) \mathrm{abcd}$ & $3,7(0,64) \mathrm{ab}$ & $3,9(0,34) \mathrm{a}$ & $11,1(1,44) \mathrm{ab}$ & $10,4(1,57) \mathrm{ab}$ \\
FlFestival & $4,3(0,21) \mathrm{a}$ & $4,3(0,83) \mathrm{abcd}$ & $4,1(0,80) \mathrm{ab}$ & $2,6(0,42) \mathrm{a}$ & $8,9(1,80) \mathrm{ab}$ & $9,7(1,57) \mathrm{ab}$ \\
IAC Guarani & $4,2(0,18) \mathrm{a}$ & $4,1(0,73) \mathrm{abcd}$ & $5,1(0,80) \mathrm{a}$ & $3,2(0,37) \mathrm{a}$ & $8,9(1,59) \mathrm{ab}$ & $8,5(2,12) \mathrm{ab}$ \\
Toyonoka & $3,9(0,17) \mathrm{a}$ & $3,5(0,66) \mathrm{bcd}$ & $4,1(0,64) \mathrm{ab}$ & $3,6(0,34) \mathrm{a}$ & $11,4(1,44) \mathrm{ab}$ & $12,1(1,64) \mathrm{ab}$ \\
Oso Grande & $3,9(0,18) \mathrm{a}$ & $3,5(0,69) \mathrm{cd}$ & $2,1(0,67) \mathrm{b}$ & $3,4(0,35) \mathrm{a}$ & $12,8(1,51) \mathrm{ab}$ & $9,4(1,97) \mathrm{ab}$ \\
Monterey & $4,4(0,20) \mathrm{a}$ & $3,5(0,78) \mathrm{cd}$ & $3,4(0,75) \mathrm{ab}$ & $2,4(0,39) \mathrm{a}$ & $13,6(1,69) \mathrm{ab}$ & $12,0(1,84) \mathrm{ab}$ \\
Albion & $3,9(0,18) \mathrm{a}$ & $3,3(0,73) \mathrm{cd}$ & $2,8(0,71) \mathrm{b}$ & $2,9(0,37) \mathrm{a}$ & $14,1(1,59) \mathrm{b}$ & $9,0(1,97) \mathrm{ab}$ \\
Camino Real & $3,9(0,21) \mathrm{a}$ & $3,3(0,83) \mathrm{cd}$ & $3,6(0,80) \mathrm{ab}$ & $2,3(0,42) \mathrm{a}$ & $12,1(1,80) \mathrm{ab}$ & $11,4(1,97) \mathrm{ab}$ \\
Dover & $3,9(0,21) \mathrm{a}$ & $3,0(0,83) \mathrm{d}$ & $3,4(0,80) \mathrm{ab}$ & $3,3(0,42) \mathrm{a}$ & $11,7(1,80) \mathrm{ab}$ & $13,9(1,73) \mathrm{a}$ \\
\hline
\end{tabular}

Mean $( \pm \mathrm{SD})$ followed by the same letter in the column did not differ by the Duncan test $(\mathrm{P}<0.05)$. 
TABLE 2- Survival percentage of egg, larva, protonymph, deutonymph and egg-adult period of Tetranychus urticae grown on leaves of different strawberry cultivars, with no choice test in the laboratory. Pelotas-RS, 2015.

\begin{tabular}{lccccc}
\hline \multirow{2}{*}{ Cultivars } & \multicolumn{5}{c}{ Survival (\%) } \\
\cline { 2 - 6 } Oso Grande & $100,0(0,00) \mathrm{a}$ & $77,8(15,71) \mathrm{a}$ & $88,9(0,00) \mathrm{a}$ & $91,7(12,42) \mathrm{a}$ & $61,1(12,42) \mathrm{a}$ \\
Toyonoka & $94,4(12,42) \mathrm{ab}$ & $75,0(29,92) \mathrm{ab}$ & $100,0(29,92) \mathrm{a}$ & $80,6(24,85) \mathrm{a}$ & $55,6(22,91) \mathrm{ab}$ \\
Serrana & $93,4(12,17) \mathrm{ab}$ & $80,0(22,78) \mathrm{a}$ & $83,3(22,79) \mathrm{a}$ & $92,8(14,95) \mathrm{a}$ & $53,8(24,85) \mathrm{abc}$ \\
Monterey & $93,3(12,97) \mathrm{ab}$ & $63,5(22,75) \mathrm{ab}$ & $100,0(22,77) \mathrm{a}$ & $89,8(24,34) \mathrm{a}$ & $53,3(24,34) \mathrm{abc}$ \\
IAC Guarani & $100,0(0,00) \mathrm{a}$ & $72,6(12,29) \mathrm{ab}$ & $100,0(12,29) \mathrm{a}$ & $73,2(14,96) \mathrm{a}$ & $52,8(14,96) \mathrm{abcd}$ \\
Ventana & $94,4(12,42) \mathrm{ab}$ & $77,8(22,01) \mathrm{a}$ & $88,9(12,42) \mathrm{a}$ & $83,3(16,67) \mathrm{a}$ & $50,0(16,67) \mathrm{abcd}$ \\
Dover & $100,0(0,00) \mathrm{a}$ & $53,3(14,91) \mathrm{ab}$ & $89,6(14,91) \mathrm{a}$ & $89,6(14,91) \mathrm{a}$ & $46,7(14,91) \mathrm{abcd}$ \\
Camino Real & $86,8(14,91) \mathrm{ab}$ & $62,3(14,96) \mathrm{ab}$ & $89,6(14,85) \mathrm{a}$ & $89,6(14,95) \mathrm{a}$ & $46,2(14,95) \mathrm{abcd}$ \\
Albion & $88,9(15,71) \mathrm{ab}$ & $63,9(15,71) \mathrm{ab}$ & $83,3(25,46) \mathrm{a}$ & $90,0(24,85) \mathrm{a}$ & $44,5(24,85) \mathrm{abcd}$ \\
Campidover & $83,3(16,67) \mathrm{ab}$ & $69,4(24,85) \mathrm{ab}$ & $77,8(24,85) \mathrm{a}$ & $90,0(22,91) \mathrm{a}$ & $38,9(22,91) \mathrm{abcd}$ \\
Camarosa & $94,4(12,42) \mathrm{ab}$ & $55,6(31,43) \mathrm{ab}$ & $90,0(31,91) \mathrm{a}$ & $73,3(19,25) \mathrm{a}$ & $33,3(19,25) \mathrm{bcd}$ \\
IAC Campinas & $88,9(15,71) \mathrm{ab}$ & $61,1(24,85) \mathrm{ab}$ & $83,3(31,91) \mathrm{a}$ & $70,0(14,96) \mathrm{a}$ & $30,5(14,96) \mathrm{bcd}$ \\
Sabrosa & $94,5(12,42) \mathrm{ab}$ & $50,0(24,85) \mathrm{ab}$ & $100,0(24,85) \mathrm{a}$ & $70,0(12,42) \mathrm{a}$ & $27,8(12,42) \mathrm{cd}$ \\
Florida Festival & $100,0(0,00) \mathrm{a}$ & $38,9(12,42) \mathrm{b}$ & $100,0(12,42) \mathrm{a}$ & $75,0(12,42) \mathrm{a}$ & $27,8(12,42) \mathrm{cd}$ \\
Aromas & $80,2(14,91) \mathrm{b}$ & $47,9(29,85) \mathrm{ab}$ & $90,5(19,31) \mathrm{a}$ & $86,7(12,29) \mathrm{a}$ & $27,4(12,29) \mathrm{cd}$ \\
Diamante & $100,0(0,00) \mathrm{a}$ & $53,3(31,03) \mathrm{ab}$ & $90,8(24,34) \mathrm{a}$ & $61,4(19,49) \mathrm{a}$ & $26,7(12,17) \mathrm{d}$ \\
\hline
\end{tabular}

Mean $( \pm \mathrm{SD})$ followed by the same letter in the column did not differ by the Duncan test $(\mathrm{P}<0.05)$.

${ }^{1}$ Variable calculated from the average of 10 replicates of the F2 generation.

TABLE 3-Fertility life table of Tetranychus urticae females in different strawberry cultivars, with no choice test in the laboratory. Pelotas-RS, 2015.

\begin{tabular}{lccccc}
\hline \multirow{2}{*}{ Cultivars } & \multicolumn{5}{c}{ Parameters } \\
\cline { 2 - 6 } & $\mathbf{R}_{\mathbf{o}}$ & IMG & $\mathbf{r}_{\mathbf{m}}$ & $\mathbf{T d}$ & $\boldsymbol{\lambda}$ \\
\hline Florida Festival & 1,96 & 22,44 & 0,030 & 23,12 & 1,030 \\
IAC Campinas & 2,96 & 24,74 & 0,044 & 15,81 & 1,045 \\
Dover & 2,97 & 22,91 & 0,048 & 14,58 & 1,049 \\
Campidover & 3,02 & 21,83 & 0,051 & 13,70 & 1,052 \\
Sabrosa & 3,92 & 25,13 & 0,054 & 12,76 & 1,056 \\
Diamante & 3,60 & 22,96 & 0,056 & 12,44 & 1,057 \\
Camarosa & 4,82 & 25,34 & 0,062 & 11,16 & 1,064 \\
IAC Guarani & 5,44 & 25,32 & 0,067 & 10,36 & 1,069 \\
Ventana & 7,12 & 25,23 & 0,078 & 8,91 & 1,081 \\
Aromas & 6,74 & 22,81 & 0,084 & 8,29 & 1,087 \\
Toyonoka & 8,35 & 24,01 & 0,088 & 7,84 & 1,092 \\
Camino Real & 7,14 & 21,97 & 0,090 & 7,74 & 1,094 \\
Albion & 8,23 & 22,26 & 0,095 & 7,32 & 1,099 \\
Serrana & 13,42 & 25,17 & 0,103 & 6,72 & 1,109 \\
Oso Grande & 11,28 & 21,56 & 0,112 & 6,17 & 1,119 \\
Monterrey & 14,84 & 22,47 & 0,120 & 5,77 & 1,128 \\
\hline
\end{tabular}

Net reproductive rate (Ro), mean interval between generations (IMG) in days, intrinsic growth rate (rm), population doubling time $(\mathrm{Td})$ and finite increase rate $(\lambda)$. 


\section{CONCLUSIONS}

The survival of T. urticae is differently influenced by strawberry cultivars, with the larval phase being the most sensitive.

Camarosa, Florida Festival, IAC Campinas and Sabrosa strawberry cultivars negatively influenced the biology of T. urticae, indicating the possibility of antibiosis resistance.

Albion, Monterrey, Oso Grande and Serrana cultivars are more favorable to the development of T. urticae, while Florida Festival and IAC Campinas cultivars are less favorable.

\section{REFERENCES}

ANTUNES, L.E.C.; DUARTE FILHO, J. Sistema de produção do morango. In: SANTOS, A.M. et al. Sistemas de produção. Pelotas: EMBRAPA CT, 2005. Disponível em: $<$ http://sistemasdeproducao. cnptia.embrapa.br/FontesHTML/Morango/ SistemaProducaoMorango/> Acesso em: 17 jun. 2015.

AWMACK, C.S.; LEATHER, S.R. Host plant quality and fecundity in herbivorous insects. Annual Review Entomology, Palo Alto, v.47, p.817-844, 2002. Disponível em: <http://www.annualreviews.org/ doi/abs/10.1146/annurev.ento.47.091201.145300> Acesso em: 17 jun. 2015. (5)

BERNARDI, D.; BOTTON, M.; SILVA, U.S.; BERNARDI, O.; MALAUSA, T.; GARCIA, M.S.; NAVA, D.E. Effects of azadirachtin on Tetranychus urticae (Acari: Tetranychidae) and its compatibility with predatory mites (Acari: Phytoseiidae) on strawberry. Pest Management Science, Malden, v.69, n.1, p.75-80, 2013. Disponível em: <http:// onlinelibrary.wiley.com/urn:doi/10.1002/ps.3364/ epdf > Acesso em: 30 jun. 2015.

ESTEVES FILHO, A.B.; OLIVEIRA, J.V; TORRES, J.B.; GONDIM JUNIOR, M.G.C. Biologia comparada e comportamento de Tetranychus urticae Koch (Acari: Tetranychidae) e Phytoseiulus macropilis (Banks) (Acari: Phytoseiidae) em Algodoeiro Bollgard $^{\mathrm{TM}}$ e Isolinha não-Transgênica. Neotropical Entomology, Londrina, v.39, n.3, p.338-344, 2010. Disponível em: $<$ http://www.scielo.br/pdf/ne/v39n3/ v39n3a05.pdf $>$ Acesso em: 30 jun. 2015.
FADINI, M.A.M.; PALLINI, A.; VENZON, M. Controle de ácaros em sistema de produção integrada de morango. Ciência Rural, Santa Maria, v.34, p.1271-1277, 2004. Disponível em: $<$ http://www. scielo.br/pdf/cr/v34n4/a53v34n4.pdf $>$ Acesso em: 17 jun. 2015.

FERLA, N.J.; MARCHETTI, M.M.; GONÇALVES, D. Ácaros predadores (Acari) associados à cultura do morango (Fragaria sp., Rosaceae) e plantas próximas no Estado do Rio Grande do Sul. Biota Neotropica, São Paulo, v.7, n.2, p.103-110, 2007. Disponível em: $<$ http://www.scielo.br/pdf/bn/v7n2/a12v07n2.pdf $>$ Acesso em: 19 jun. 2015.

FIGUEIREDO, A.S.T.; RESENDE, J.T.V.; SANTOS, A.P.G.; CAMARGO JÚNIOR, O.; MORALES, R.G.F.; FARIA, M.V.; PRECZENHAK, A.P. Repelência de cultivares de morangueiro ao ácaro rajado, mediada por tricomas presentes nos folíolos. Horticultura Brasileira, Brasília, DF, v.28, n.2, p.603-609, 2010. Disponível em: $<$ http://www. abhorticultura.com.br/eventosx/trabalhos/ev_4/ a2662 t4972 comp.pdf $>$ Acesso em: 19 jun. 2015.

GONÇALVES, L.D.; MALUF, W.R.; CARDOSO, M.G.; RESENDE, J.T.V.; CASTRO, E.M.; SANTOS, N.M.; NASCIMENTO, I.R.; FARIA, M.V. Relação entre zingibereno, tricomas foliares e repelência de tomateiros a Tetranychus evansi. Pesquisa Agropecuária Brasileira, Brasília, DF, v.41, n.2, p.267-273, 2006. Disponível em: < http://www. scielo.br/pdf/pab/v41n2/a11v41n2.pdf $>$ Acesso em: 19 jun. 2015.

KASAP, I. Effect of apple cultivar and of temperature on the biology and life table parameters of the twospotted spider mite Tetranychus urticae. Phytoparasitica, Rehovolt v.32, n.1, p.73-82, 2004. Disponível em: $<$ http://link.springer.com/ article/10.1007/BF02980863> Acesso em: 30 jun. 2015.

KISHABA, A.N.; VOTH, V.; HOWLAND, A.F.; BRINGHURST, R.S.; TOBA, H.H. Twospotted spider mite resistance in California strawberries. Journal of Economic Entomology, Lanham, v.65, n.1, p.117-119, 1972. 
KRIPS, O.E.; WILTUL, A.; WILLEMS, P.E.L.; DICKE, M. Intrinsic rate of population increase of the spider mite Tetranychus urticae on the ornamental crop gerbera: intraspecific variation in host plant and herbivore. Entomologia Experimentalis et Applicata, Dordrecht, v.89, p.159-168, 1998. Disponível em: <http://onlinelibrary.wiley.com/ urn:doi/10.1046/j.1570-7458.1998.00395.x/epdf > . Acesso em: 30 jun. 2015.

LABANOWSKA, B.H. Susceptibility of strawberry cultivars to the two-spotted spider mite. Journal of Fruit and Ornamental Plant Research, Poland, v.15, p.133-146, 2007. Disponível em: <http://www. insad.pl/files/journal_pdf/journal_2007/Full13\%20 2007.pdf $>$. Acesso em: 26 jun. 2015.

LARA, F., M. Princípios de resistência de plantas a insetos. 2.ed. São Paulo: Ícone, 1991. 336p.

LOURENÇÃO, A.L.; MORAES, G.J.; PASSOS, F.A.; AMBROSANO, G.M.B.; SILVA, L.V.F. Resistência de morangueiros a Tetranychus urticae Koch (Acari: Tetranychidae). Anais da Sociedade Entomológica do Brasil, Jaboticabal, v.29, n.2, p.339-346, 2000. Disponível em: $<$ http://www.scielo. br/pdf/aseb/v29n2/v29n2a16.pdf $>$. Acesso em: 26 jun. 2015.

LUCZYNSKI, A.; ISMAN, M.B.; RAWORTH, D.A.; CHAN, C.K. Chemical and morphological factors of resistance against the twospotted spider mite in beach strawberry. Journal of Economic Entomology, Lanham, n.83, p.564-569, 1990. Disponível em:<http://jee.oxfordjournals.org/ content/83/2/564> Acesso em: 30 jun. 2015.

MONTEIRO, L.B.; KUNH, T.M.A.; MOGOR, A.F.; SILVA, E.D.B. Biology of the two-spotted spider mite on strawberry plants. Neotropical Entomology, Londrina, v.43, p.183-188, 2014. Disponível em: <http://www.ncbi.nlm.nih.gov/pmc/articles/ PMC3958812/pdf/13744 2013 Article 184.pdf>. Acesso em 30 jun. 2015.

MORAES, G.J.; FLECHTMANN, C.H.W. Manual de Acarologia: acarologia básica e ácaros de plantas cultivadas no Brasil. Ribeirão Preto: Holos Editora, 2008. $288 \mathrm{p}$.
MORO, L.B.; POLANCZYKI, R.A.; CARVALHO, J.R.; PRATISSOLI, D.; FRACOL, C.R. Parâmetros biológicos e tabela de vida de Tetranychus urticae (Acari: Tetranychidae) em cultivares de mamão. Ciência Rural, Santa Maria, v.42, n.3, p.487-493, 2012. Disponível em: $\leq$ http://www.scielo.br/pdf/cr/ v42n3/a7912cr5539.pdf $>$ Acesso em: 30 jun. 2015.

REZAIE, M.; SABOORI, A.; BANIAMERIE, V.; ALLAHYARI, H. Susceptibility of Tetranychus uticae Koch (Acari: Tetranychidae) on seven strawberry cultivars. International Research Journal of Applied and Basic Sciences, Sher-eBangla, v.4, n.9, p.2455-2463, 2013.

SATO, M.E.; SILVA, M.Z.; SILVA, R.B.; SOUZA FILHO, M.F.; RAGA, A. Monitoramento da resistência de Tetranychus urticae Koch (Acari: Tetranychidae) a abamectin e fenpyroxymate em diversas culturas no Estado de São Paulo. Arquivos do Instituto Biológico, São Paulo, v.76, n.2, p.217223, 2009. Disponível em: <http://www.biologico. sp.gov.br/docs/arq/v76 2/sato.pdf $>$ Acesso em: 30 jun. 2015.

SILVA, M.A.; PARRA, J.R.P.; CHAVEGATO, L.G. Biologia comparada de Tetranychus urticae em cultivares de algodoeiro: tabela de vida de fertilidade. Pesquisa Agropecuária Brasileira, Brasília, DF, v.20, n.9, p.1015-1019, 1985. Disponível em: $<\underline{\text { http://seer.sct.embrapa.br/index.php/pab/article/ }}$ view/16172/10340> Acesso em: 30 jun. 2015.

SILVEIRA NETO, S.; NAKANO, O.; BARBADIN, D.; VILLA NOVA, N.A. Manual de ecologia dos insetos. Piracicaba: Ceres, 1976. 416p.

STEINITE, I.; IEVINSH, G. Possible role of trichomes in resistance of strawberry cultivars against spider mite. Acta Universitatis Latviensis, Riga, v.662, p.59-65, 2003. Disponível em: $<$ http:// eeb.lu.lv/EEB/2003/Steinite.pdf $>$ Acesso em: 30 jun. 2015 .

WATANABE, M.A.; MORAES, G.J.; GASTALDO JR, I.; NICOLELLA. G. Controle biológico do ácaro rajado com ácaros predadores fitoseídeos (Acari: Tetranychidae, Phytoseiidae) em cultura de pepino e morango. Scientia Agricola, Piracicaba, v.51, p.7581, 1994. Disponível em: $<$ http://www.scielo.br/pdf/ sa/v51n1/12.pdf $>$ Acesso em: 30 jun. 2015. 